\title{
Long-term effect of maternal obesity on pancreatic beta cells of offspring: reduced beta cell adaptation to high glucose and high-fat diet challenges in adult female mouse offspring
}

Received: 10 January 2005 / Accepted: 16 April 2005 / Published online: 12 July 2005

(C) Springer-Verlag 2005

\begin{abstract}
Aim/hypothesis: Obesity is a global problem with high risks of cardiovascular diseases, stroke and type 2 diabetes. It is well known that maternal obesity affects offspring by inducing malformation, functional abnormalities in many organs and cells, and by increased risk of obesity and type 2 diabetes. However, little is known about abnormalities induced by maternal obesity in pancreatic beta cells of offspring. Methods: We used mouse mothers with the Agouti yellow modification on a C57BL/6 background as a maternal model of normoglycaemic obesity, and produced Agouti-negative offspring. Half of the offspring were fed a high-fat diet. Offspring glucose tolerance was tested at different ages, and animals were killed at 50 weeks of age for islet function analysis. Results: Maternal obesity impaired glucose tolerance in female offspring fed a high-fat diet, and significantly reduced insulin secretion at 50 weeks of age in female offspring that had been fed a normal diet and high-fat diet. Insulin secretion and glucose potentiation from these islets were significantly reduced. Islet protein, DNA and insulin contents were increased while glyceraldehyde-3-phosphate dehydrogenase and transketolase activities were reduced in female offspring. Conclusions/interpretation: Our results indicate that maternal obesity has a long-term effect on the beta cells of female, but not of male, offspring, and leads to increased risk of gestational diabetes and type 2 diabetes in the offspring's later lives.
\end{abstract}

J. Han · J. Xu · P. N. Epstein · Y. Q. Liu $(\bowtie)$

The Kosair Children's Hospital Research Institute, Department of Pediatrics,

University of Louisville School of Medicine,

570 South Preston Street, Suite 304,

Louisville, KY 40202, USA

e-mail: yqliu001@gwise.louisville.edu

Tel.: +1-502-8522654

Fax: $+1-502-8525634$

P. N. Epstein · Y. Q. Liu

Department of Pharmacology and Toxicology,

University of Louisville School of Medicine,

Louisville, KY 40202, USA
Keywords Beta cell adaptation · Insulin secretion · Islets of Langerhans · Maternal obesity · Offspring - Type 2 diabetes mellitus

Abbreviations $A^{y}$ : Agoutin mutation $\cdot \mathrm{L}: \mathrm{C} 57 \mathrm{BL} / 6 \mathrm{~J}$ mice - GAPDH: glyceraldehyde-3-phosphate dehydrogenase - HFD: high-fat diet - PFK: phosphofructokinase

\section{Introduction}

More than $18 \%$ of American women meet the criteria for obesity $[1,2]$ and 18 to $38 \%$ of pregnant women in the United States are obese [3]. Obesity during pregnancy has implications for morbidity and mortality in both mother and baby $[4,5]$. One of the possible risks to the baby is the eventual development of type 2 diabetes [6]. Maternal obesity could therefore be one of the factors contributing to the alarming rise in the prevalence of diabetes.

It is well known that a prenatal diabetic environment greatly increases the risk of type 2 diabetes in the offspring [7-10]. The mechanism of this propensity to diabetes in the offspring is not well understood. Diabetes and obesity are frequently co-morbid conditions and maternal obesity could be one factor contributing to the ultimate development of diabetes in the offspring. Unfortunately, few studies have attempted to establish whether obesity in the absence of diabetes can promote glucose intolerance or diabetes in the offspring.

In the current study, we tested whether maternal obesity in mice, in the absence of diabetes, can impair glucose tolerance in genetically normal offspring. We used mothers carrying the Agouti $\left(A^{y}\right)$ mutation on a $\mathrm{C} 57 \mathrm{BL} / 6$ background. On this background, the $A^{y}$ mutation produces marked obesity without diabetes. Adult, genetically normal, offspring of $A^{y}$-positive mothers were tested for their capacity to maintain normal glucose homeostasis.

Studies of the effect of maternal diabetes or obesity have demonstrated insulin resistance in the offspring [6, $11,12]$. However, diabetes will not occur unless there is 
also a reduction in pancreatic beta cell function $[13,14]$. Until now, the impact of maternal diabetes or obesity on long-term beta cell function in the offspring has not been tested. In this study, we found sex-related changes in beta cell function due to maternal obesity. Our results indicate that maternal obesity can lead to problems in glucose tolerance in adult offspring and that deficits in the pancreatic beta cell play an important role.

\section{Materials and methods}

Animals The principles of animal laboratory care under the guidelines of both the National Institutes of Health and the University of Louisville's Animal Care Committee were followed strictly. Female obese $A^{y} / \mathrm{C} 57 \mathrm{BL} / 6 \mathrm{~J}$ mice (L) mice (the yellow mutation, $A^{y}$, on an $\mathrm{L}$ background) and normal male L mice (both from the Jackson Laboratory, Bar Harbor, ME, USA), aged 10 weeks, were used for mating. In litters from Agouti/L mothers, $A^{y}$ positive and $A^{y}$-negative offspring are easily distinguished by their distinct coat colors. Agouti/L mice become obese around 6-8 weeks of age [15]. The body weights and blood glucose levels of Agouti/L and L mothers are shown in Table 1. Body weights of Agouti/L mothers during pregnancy were significantly higher than those of control $\mathrm{L}$ mothers, but blood glucose levels were the same as control mothers, demonstrating that the Agouti/L mothers provided a good model of obesity without diabetes. $A^{y}$ negative offspring of Agouti/L mothers were used for this research. Offspring of $\mathrm{L}$ mothers were used as control animals. The animals received normal chow up to 15 weeks of age, then the animals were divided into two groups. Half of the offspring (male and female, and control L and $A^{y}$-negative offspring) were fed with a high-fat diet (HFD; $60 \%$ energy from fat $[21 \%$ casein, $15 \%$ sucrose, $18 \%$ cornstarch, 5\% corn oil, 31\% lard], as powder, from TestDiet, Richmond, IN, USA) starting at 15 weeks of age, the other half received a basal diet $(22 \%$ energy from fat $[21 \%$ casein, $15 \%$ sucrose, $43 \%$ cornstarch, $5 \%$ corn oil, $5 \%$ lard], as powder, from TestDiet). All animals had free access to food. We chose 15 weeks of age to start high-fat feeding, because we wanted to observe adult offspring beta cell adaptation. All animals were housed in the Animal Care Facility at the University of Louisville and maintained at $25^{\circ} \mathrm{C}$ with a 12 -h light/dark cycle.
Body weight was measured and blood collected, after tail snipping, at weekly intervals. Blood glucose was measured regularly with a portable glucose meter (Johnson \& Johnson Company, New Brunswick, NJ, USA). For measurement of serum insulin, blood samples of mice were collected into heparinised capillary tubes and serum was stored at $-20^{\circ} \mathrm{C}$ pending insulin assay. Mice were killed for islet isolation at 50 weeks of age.

Glucose tolerance test and insulin assay After an overnight fast, mice were administered glucose intraperitoneally $(1 \mathrm{~g} / \mathrm{kg}$ body weight or $2 \mathrm{~g} / \mathrm{kg}$ body weight as indicated). Blood samples were taken after tail snipping at various time points $(0,15,30,60$ and $120 \mathrm{~min})$, and blood glucose was determined as described above. Serum insulin levels at 0,15 , and 30 min time points were determined with the Ultrasensitive Mouse Insulin-ELISA Test Kit (Mercodia Company, Sylveniusgaten, Uppsala, Sweden).

Islet isolation Islets were isolated from mice by an adaptation of the Gotoh method [16]: pancreas duct infiltration with collagenase, Histopaque gradient separation and hand-picking. Before performing measurements, islets were cultured for $1 \mathrm{~h}$ at $37^{\circ} \mathrm{C}$ in humidified air and $5 \%$ $\mathrm{CO}_{2}$ in RPMI 1640 supplemented with $5.5 \mathrm{mmol} / \mathrm{l}$ glucose, and $10 \%$ newborn calf serum, $2 \mathrm{mmol} / \mathrm{l}$ glutamine, $100 \mathrm{U} / \mathrm{ml}$ penicillin, $0.1 \mathrm{mg} / \mathrm{ml}$ streptomycin (all from Gibco, Grand Island, NY, USA).

Insulin secretion Ten islets were cultured in each 5-ml vial with $1 \mathrm{ml} \mathrm{KRB} \mathrm{(Krebs-Ringer} \mathrm{bicarbonate} \mathrm{buffer} \mathrm{sup-}$ plemented with $10 \mathrm{mmol} / 1 \mathrm{HEPES}, \mathrm{pH} 7.4$ and $0.1 \%$ BSA, bubbled with $5 \% \mathrm{CO}_{2}, 95 \% \mathrm{O}_{2}$ ) containing 2.8 or $16.7 \mathrm{mmol} / \mathrm{l}$ glucose in a $37^{\circ} \mathrm{C}$ shaking water-bath as previously described [17]. After incubation for $60 \mathrm{~min}$, vials were moved from the water-bath to ice to stop the reaction, followed by a brief centrifugation at $4^{\circ} \mathrm{C}, 0.5 \mathrm{ml}$ $\mathrm{KRB}$ was moved into a glass tube and stored at $-20^{\circ} \mathrm{C}$ pending assay for insulin as described above.

Islet DNA, protein and insulin contents DNA was measured by the Labarca method [18] and protein by a commercial kit that used BSA as standard (Bio-Rad, Hercules, CA, USA). Islets were homogenised in acid-ethanol and stored at $-20^{\circ} \mathrm{C}$ pending assay for insulin contents as described above.

Table 1 Body weight and fed blood glucose levels of Agouti and control mothers during pregnancy and 1 week after delivery

\begin{tabular}{|c|c|c|c|c|c|c|c|c|}
\hline & \multicolumn{4}{|c|}{ Body weight } & \multicolumn{4}{|c|}{ Fed blood glucose } \\
\hline & Week 1 & Week 2 & Week 3 & Week 4 & Week 1 & Week 2 & Week 3 & Week 4 \\
\hline $\mathrm{L}$ & $16.1 \pm 0.9$ & $17.3 \pm 1.1$ & $18.8 \pm 1.5$ & $21.5 \pm 3.6$ & $145.5 \pm 24.7$ & $155.5 \pm 17.1$ & $168.3 \pm 41.6$ & $144.5 \pm 6.1$ \\
\hline$p$ values & NS & $<0.05$ & $<0.05$ & $<0.05$ & NS & NS & NS & NS \\
\hline
\end{tabular}

Agouti and control females were mated with C57BL/6 males at 10 weeks of age. Week 1 to Week 3 is pregnancy. Week 4=1 week after delivery. L, control mothers; $A^{y} \mathrm{~L}$, Agouti-positive mothers. Data are means $\pm \mathrm{SD} ; n=8$ for each group 
GAPDH activity assay The assay measured the appearance of NADH absorbance at $340 \mathrm{~nm}$ as described by Lambeir et al. [19]. Reaction mixtures $(1 \mathrm{ml})$ contained $0.01 \mathrm{~mol} / 1$ triethanolamine $/ \mathrm{HCl}, \mathrm{pH} 7.6,1 \mathrm{mmol} / 1$ dithiothreitol, $1 \mathrm{mmol} / 1$ EDTA, $0.1 \mathrm{~mol} / 1 \mathrm{KCl}, 10 \mathrm{mmol} / 1$ potassium phosphate, $1 \mathrm{mmol} / \mathrm{l} \mathrm{NAD}$ and $0.8 \mathrm{mmol} / 1$ glyceraldehyde-3-phosphate. Reactions were initiated by addition of $10 \mu \mathrm{l}$ of islet extract. Reactions were carried out at $25^{\circ} \mathrm{C}$. Absorbance at $340 \mathrm{~nm}$ was measured on a Hitachi 2500 spectrophotometer (Technical Lab Services, Toronto, ON, Canada) for $10 \mathrm{~min}$. Glyceraldehyde-3phosphate dehydrogenase (GAPDH) activity was confirmed by measuring the conversion of NADH to $\mathrm{NAD}^{+}$at $340 \mathrm{~nm}$ in the backward reaction starting with glycerate-3phosphate using glycerate-3-phosphate kinase plus ATP as described previously [20].

Phosphofructokinase activity assay Islets were sonicated on ice in $0.15 \mathrm{ml}$ of extraction buffer containing $15 \mathrm{mmol} / 1$ $\mathrm{K}_{2} \mathrm{PO}_{4}, \mathrm{pH} 7.0,100 \mathrm{mmol} / \mathrm{l} \mathrm{KCl}, 2 \mathrm{mmol} / \mathrm{l}$ EDTA, 2 $\mathrm{mmol} / \mathrm{l}$ phenylmethylsulfonyl fluoride, $0.2 \mathrm{mg} / \mathrm{ml}$ leupeptin and $50 \mu \mathrm{g} / \mathrm{ml}$ aprotinin. After centrifugation at 12,000 $g$ for $15 \mathrm{~min}$ at $4^{\circ} \mathrm{C}$, phosphofructokinase (PFK) activity was measured by a previously described method [17]. Supernatant was added to $1 \mathrm{ml}$ buffer that contained 50 $\mathrm{mmol} / \mathrm{l}$ Tris/HCl, pH 8.0, $1 \mathrm{mmol} / \mathrm{l}$ EDTA, $2.5 \mathrm{mmol} / \mathrm{l} \mathrm{di}-$ thiothreitol, $5 \mathrm{mmol} / 1$ ammonium sulfate, $2 \mathrm{mmol} / 1 \mathrm{MgCl}_{2}$, $1 \mathrm{mmol} / 1 \mathrm{ATP}, 1 \mathrm{mmol} / \mathrm{l}$ fructose- 6 -phosphate, $0.16 \mathrm{mmol} / 1$ $\mathrm{NADH}, 0.4 \mathrm{U} / \mathrm{ml}$ aldolase, and $2.4 \mathrm{U} / \mathrm{ml}$ triose phosphate isomerase plus $0.8 \mathrm{U} / \mathrm{ml}$ glycerophosphate dehydrogenase mixture (Boehringer Mannheim, Indianapolis, IN, USA) in a quartz cuvette. The NADH metabolised was assessed at $340 \mathrm{~nm}$ by spectrophotometry. PFK activity was calculated based on $1 \mu \mathrm{mol}$ fructose-1,6-diphosphate $=2 \mu \mathrm{mol}$ NADH consumed.

Transketolase activity assay Islets were washed with PBS $0.5 \mathrm{ml}$, three times, and homogenised in $100 \mu \mathrm{l}$ of 10 $\mathrm{mmol} / \mathrm{l}$ HEPES, $\mathrm{pH} 7.4,250 \mathrm{mmol} / 1$ sucrose, $2.5 \mathrm{mmol} / 1$ EDTA, $2 \mathrm{mmol} / \mathrm{l}$ cysteine, and $0.02 \% \mathrm{BSA}$. The catalytic activity of transketolase was measured spectrophotometrically at $340 \mathrm{~nm}$ at $25^{\circ} \mathrm{C}$ by the rate of $\mathrm{NAD}^{+}$reduction in a coupled system with glyceraldehyde phosphate dehydrogenase [21]. The reaction mixture (final volume $0.6 \mathrm{ml}$ ) contained $50 \mathrm{mmol} / 1$ glycylglycine, $5 \mathrm{mmol} / \mathrm{l}$ sodium arsenate, $0.25 \mathrm{mmol} / 1 \mathrm{NAD}^{+}, 3 \mathrm{U}$ glyceraldehydephosphate dehydrogenase, $3 \mathrm{mmol} / 1$ dithiothreitol, $2.5 \mathrm{mmol} / 1 \mathrm{CaCl}_{2}$, $0.1 \mathrm{mmol} / 1 \mathrm{ThDP}$ and $7 \mathrm{mmol} / 1$ phosphopentoses (xylulose-5-phosphate+ribose-5-phosphate); $\mathrm{pH}$ 7.6. The reaction was initiated by islet extract addition.

Data presentation and statistical methods All data are expressed as means $\pm \mathrm{SD}$. Unless otherwise stated, the listed $n$ values represent the number of experiments performed. Comparisons between two groups were performed by Student's $t$-test. Comparisons between multiple groups were performed by one-way or two-way ANOVA. A value of $p<0.05$ was considered significant.

\section{Results}

Offspring birthweight and body weight Maternal obesity increased the birthweight of offspring. As shown in Fig. 1a, $A^{y}$-negative pups born of obese $A^{y}$-positive mothers weighed $14 \%$ more than control pups born of normal mothers. This effect was not maintained into adulthood (Fig. 1b). At 20, 30 and 50 weeks of age body weights of $A^{y}$-negative offspring and control offspring were not significantly different. From Fig. 1b it can be seen that the HFD markedly increased body weight in $A^{y}$-negative and control animals.

Blood glucose and serum insulin levels following a glucose challenge Fifty-week-old $A^{y}$-negative and control animals were subject to glucose tolerance tests using doses of 1 and $2 \mathrm{mg}$ glucose/g body weight. As shown in Fig. 2, blood glucose curves were similar in female $A^{y}$-negative
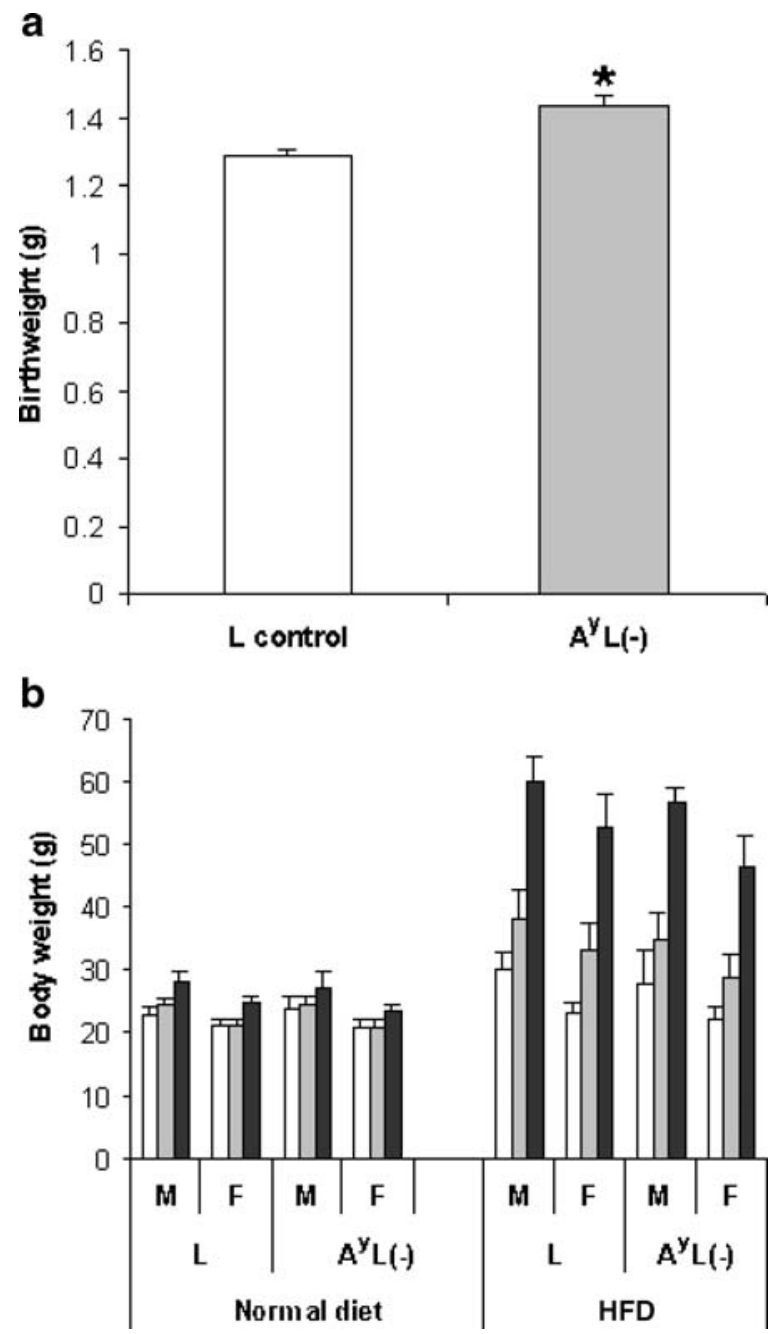

Fig. 1 Birthweight (a) and body weight gain rate (b) of offspring of control (L) and Agouti obese mothers. Male and female offspring were mixed in birthweight, but Agouti-positive offspring were excluded. Open bars 20 weeks; shaded bars 30 weeks; dark shaded bars 50 weeks. $A^{y} \mathrm{~L}(-)$, Agouti-negative offspring; M, male; F, female. Data are means \pm SD. ${ }^{*} p<0.05$ compared with control. $n=80$ (a), $n=8-10$ (b) 
Fig. 2 Glucose tolerance tests with i.p. injection of $1 \mathrm{~g}$ glucose/kg body weight (a) and $2 \mathrm{~g}$ glucose $/ \mathrm{kg}$ body weight (b). Insulin levels in glucose tolerance test blood samples of 50-week-old control and Agouti-negative female offspring fed with a normal diet after i.p. injection of $1 \mathrm{~g}$ glucose/kg body weight (c) and $2 \mathrm{~g}$ glucose/kg body weight (d). Open diamonds control offspring; closed squares Agoutinegative offspring. Data are means \pm SD. ${ }^{*} p<0.01$ compared with control; $n=8-10$
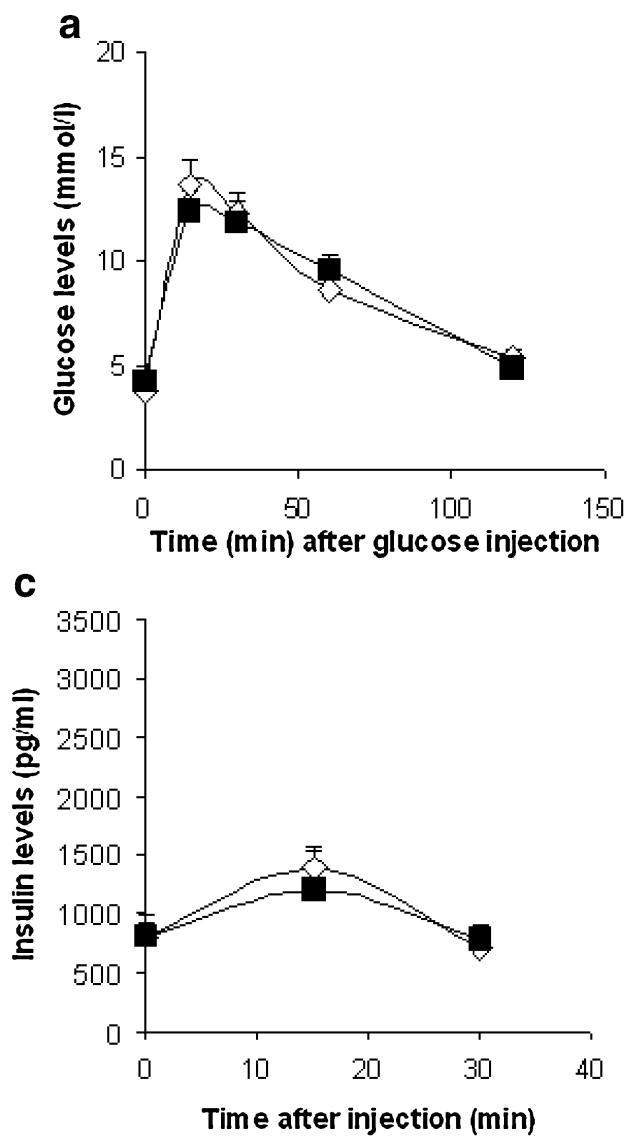

b
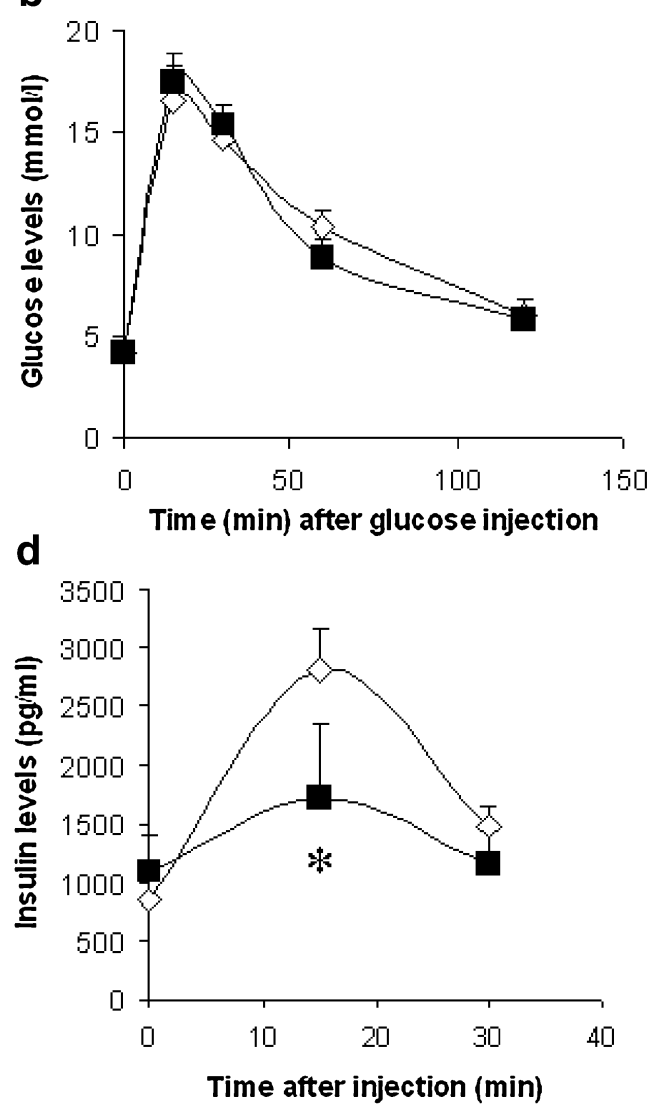

and control offspring at both doses of glucose. Serum insulin values were similar following the $1 \mathrm{mg}$ glucose dose. However, following the $2 \mathrm{mg}$ dose, serum insulin values peaked at a much higher level in control offspring than in $A^{y}$-negative offspring. In males, there was no significant difference in blood glucose or serum insulin at either dose of glucose (data not shown). This result suggested that female $A^{y}$-negative offspring have a lower capacity to secrete insulin. We tested whether a chronic high-fat diet exacerbated the differences observed between $A^{y}$-negative and control offspring. Female (Fig. 3) and male (Fig. 4) offspring fed the HFD from 15 weeks of age were injected with $1 \mathrm{mg}$ glucose/g body weight at three ages. The high-fat diet exacerbated glucose intolerance, especially in $A^{y}$-negative female mice. At 30 and 50 weeks of age the female $A^{y}$-negative serum insulin response was significantly reduced compared with control offspring. In 50 -week-old $A^{y}$-negative females, blood glucose levels were significantly higher than those measured in control offspring. Unlike females, in males a high-fat diet did not produce large differences between $A^{y}$-negative and control offspring. These results indicate that insulin secretion is reduced in female $A^{y}$-negative offspring and that this deficit is aggravated by a high-fat diet.

Insulin secretion from isolated islets of control and $A^{y}$ negative female offspring To determine if the reduction in serum insulin in $A^{y}$-negative females was associated with reduced beta cell secretion, we assayed insulin secretion in isolated islets from 50-week-old offspring that had been fed normal and high-fat diets. The results shown in Fig. 5 indicate that insulin secretion was similar in islets from control and $A^{y}$-negative offspring fed a normal diet, which is consistent with the serum insulin levels shown in Fig. 2c. However, following the HFD, insulin secretion was significantly reduced in $A^{y}$-negative islets $(p<0.05)$ compared with control islets when stimulated with 16.7 $\mathrm{mmol} / \mathrm{l}$ glucose or $16.7 \mathrm{mmol} / 1$ glucose plus $10 \mathrm{mmol} / 1$ arginine. Notably, the basal secretory levels were not different, suggesting that the decrease was related to the ability of high glucose to stimulate secretion. This result is consistent with what we found for serum insulin in highfat-fed $A^{y}$-negative offspring (Fig. 3), where the deficit in $A^{y}$-negative offspring occurred only after glucose injection.

Islet protein, DNA and insulin contents in control and $A^{y}$ negative islets We measured protein (Fig. 6a), DNA (Fig. 6c) and insulin (Fig. 6c) contents in islets from 50-week-old $A^{y}$-negative female offspring fed a normal diet. $A^{y}$-negative islet protein and DNA contents were increased about two-fold and $A^{y}$-negative islet insulin content was increased 1.4-fold. Islet yields from mice fed a high-fat diet were low and they were analysed only for insulin content. High-fat feeding increased islet insulin content in control islets but did not significantly affect insulin content of $A^{y}$-negative islets. 

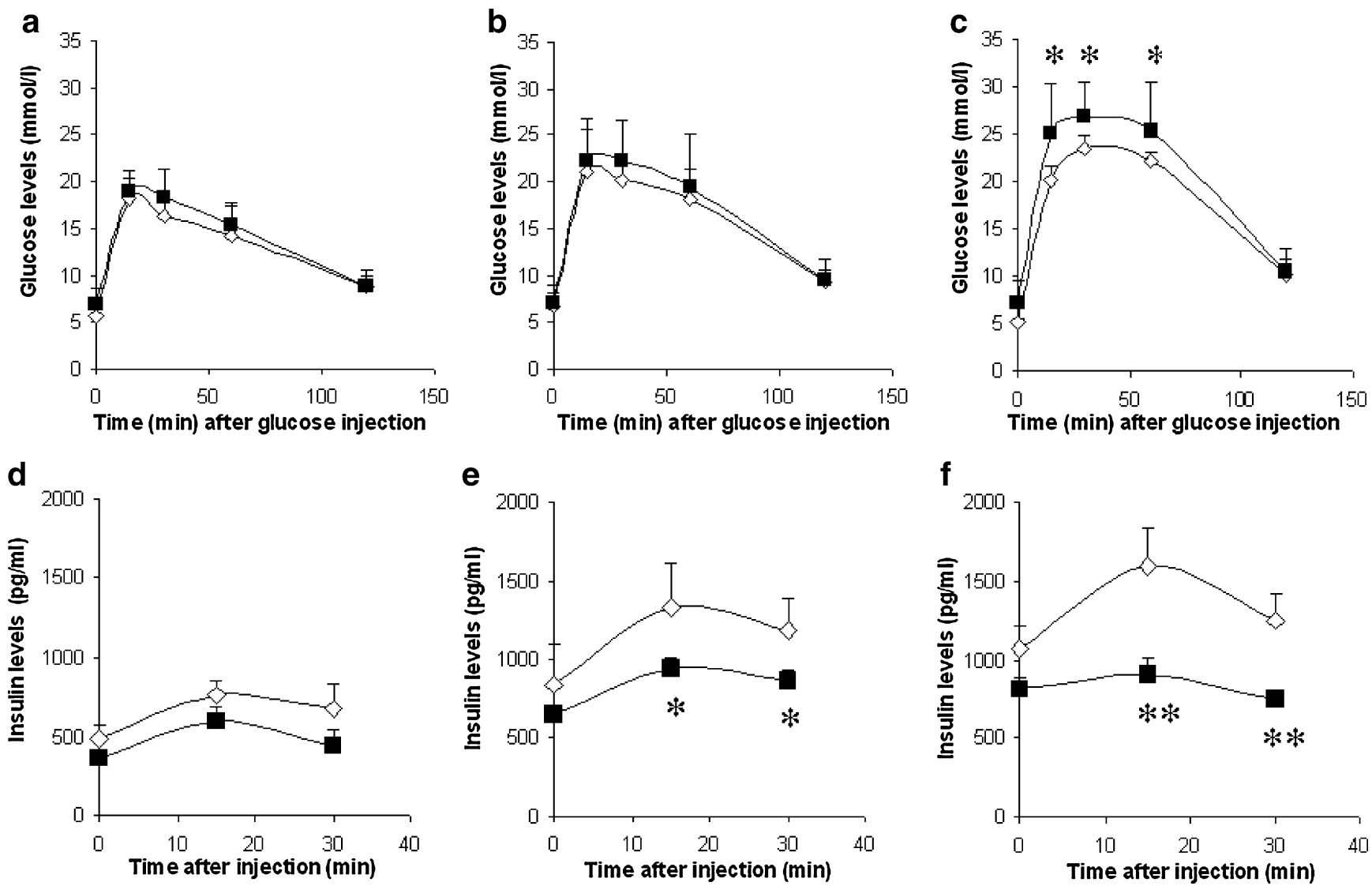

Fig. 3 Glucose tolerance tests at 20 weeks (a), 30 weeks (b) and 50 weeks (c). $1 \mathrm{~g}$ glucose $/ \mathrm{kg}$ body weight was injected i.p. Insulin levels in glucose tolerance test (1 g glucose $/ \mathrm{kg}$ body weight) blood samples from control and Agouti-negative female offspring fed the

HFD measured at 20 weeks (d), 30 weeks (e) and 50 weeks (f). Open diamonds control offspring; closed squares Agouti-negative offspring. Data are means \pm SD. ${ }^{*} p<0.05, * * p<0.01$ compared with control; $n=8-10$

Transketolase, GAPDH and PFK activities in 50-week-old control and $A^{y}$-negative female offspring islets To better understand the altered islet function, selected metabolic enzymes were measured in islets from 50-week-old female control and $A^{y}$-negative mice fed a normal diet. Transketolase, a key enzyme in the non-oxidative branch [22] of the pentose phosphate pathway was significantly reduced in $A^{y}$-negative islets (Fig. 7a). The glycolytic enzyme, GAPDH was reduced by $72 \%$ in $A^{y}$-negative islets (Fig. 7b). Under normal feeding conditions, PFK was not reduced in $A^{y}$-negative islets (Fig. 7c). PFK was also measured in islets isolated from high-fat-fed mice, in which there was a significant reduction in $A^{y}$-negative PFK activity compared with PFK activity in control islets.

\section{Discussion}

Clinical studies have demonstrated that maternal diabetes increases the offspring's risk of developing type 2 diabetes $[11,23,24]$. Basic research in animal models of diabetes has shown similar effects $[7,25,26]$. However, neither clinical nor animal studies have clearly pinpointed whether it is the effects of maternal obesity or the effects of maternal diabetes that predisposes to type 2 diabetes in the offspring. To look at the effects of obesity indepen-

dently of diabetes, we used $A^{y}$ mothers on a C57BL/6 background. As shown in Table 1, these female mice were obese but never became diabetic, even during pregnancy. Our analysis of their genetically normal offspring showed that maternal obesity induced impaired glucose tolerance in offspring with several features: (1) female $A^{y}$-negative offspring on a normal diet exhibited impaired insulin secretion when challenged with an injection of $2 \mathrm{mg}$ glucose/g body weight (Fig. 2); (2) in female offspring subjected to prolonged high-fat feeding, the impairment in insulin secretion due to an obese mother was exacerbated and these offspring also exhibited an abnormal glucose tolerance curve.

To our knowledge, this is the first report to show that obesity alone during pregnancy impairs glucose tolerance in offspring. This may contribute to the development of gestational diabetes and type 2 diabetes in these offspring. Since there are many times more obese mothers than diabetic mothers $[1-3,27]$, maternal obesity may be an important factor contributing to the overall rise of type 2 diabetes in the population.

The reduced serum insulin values in female $A^{y}$-negative offspring suggested a defect in pancreatic beta cells. To test this directly we isolated islets from 50 -week-old female offspring. The ability of glucose to stimulate insulin secretion was markedly reduced in $A^{y}$-negative islets that 
a
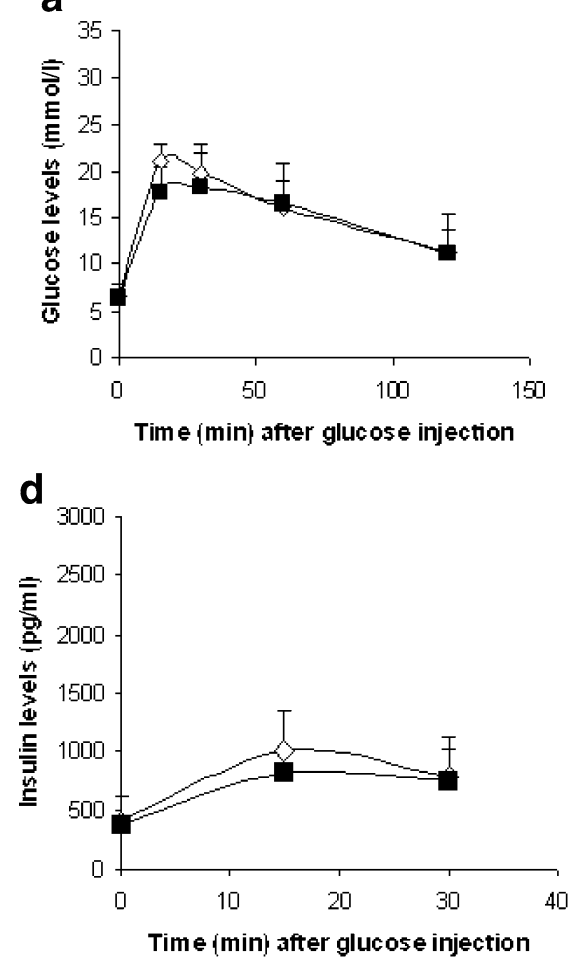

b

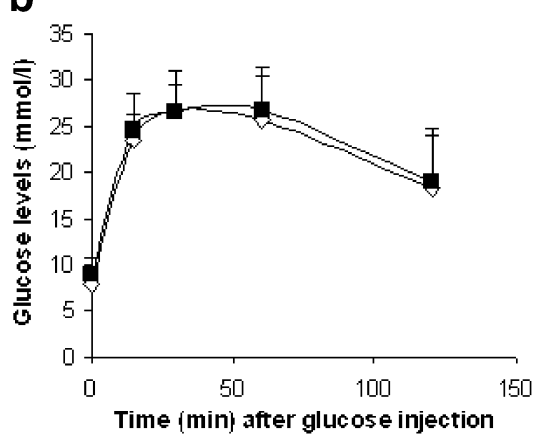

e

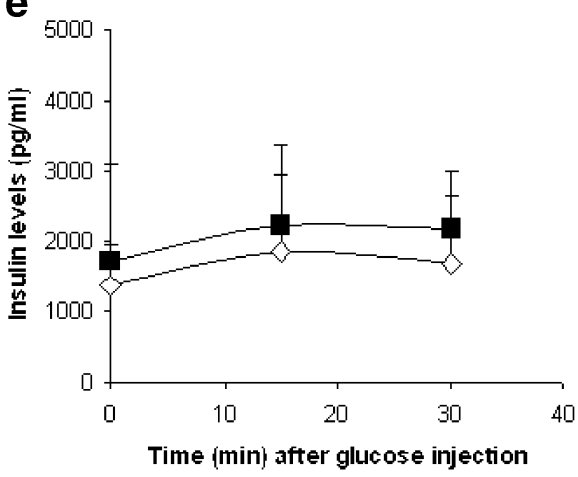

C

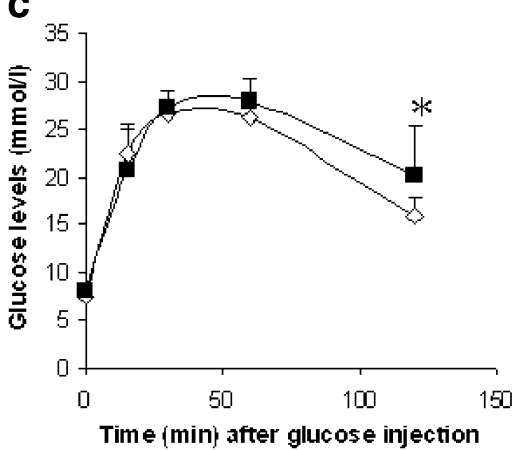

f

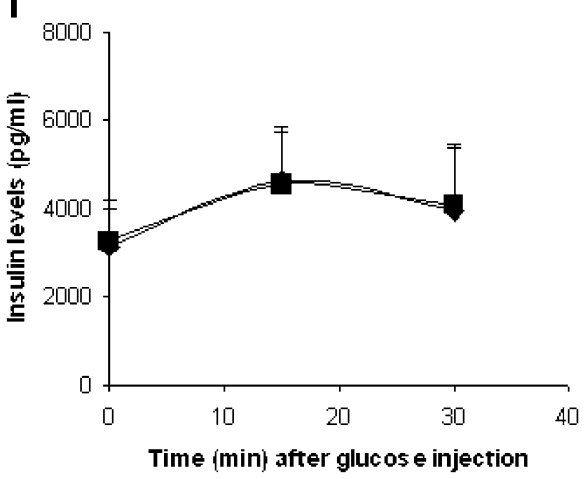

Fig. 4 Glucose tolerance tests at 20 weeks (a), 30 weeks (b) and 50 weeks (c). $1 \mathrm{~g}$ glucose $/ \mathrm{kg}$ body weight was injected i.p. Insulin levels in glucose tolerance test $(1 \mathrm{~g}$ glucose $/ \mathrm{kg}$ body weight) blood samples from control and Agouti-negative male offspring fed the
HFD measured at 20 weeks (d), 30 weeks (e) and 50 weeks (f). Open diamonds control offspring; closed squares Agouti-negative offspring. Data are means $\pm \mathrm{SD}, * p<0.05$ compared with control; $n=8-10$ had received a chronic HFD. This corresponded well to the low serum insulin levels we measured in vivo. Highfat feeding revealed functional deficits in $A^{y}$-negative islets that were small or undetectable when $A^{y}$-negative offspring were fed normal chow. At this time, it is unclear whether the impact of high-fat feeding was due to the need for beta cells to compensate for prolonged insulin resistance induced by high fat or to a direct toxic effect of elevated serum lipids on the beta cell $[28,29]$.

Despite relatively normal insulin secretion, islets from $A^{y}$-negative female offspring that had been fed normal chow were not normal. They were significantly larger than
Fig. 5 Insulin secretion from the islets of 50-week-old control and Agouti-negative female offspring fed with normal and high-fat diets. Shaded bars, Agouti-negative offspring; open bars, control offspring. $2.8=2.8$ $\mathrm{mmol} / \mathrm{l}, 16.7=16.7 \mathrm{mmol} / \mathrm{l} \mathrm{glu}-$ cose concentration in $\mathrm{KRB}$, respectively; $\mathrm{Arg}=10 \mathrm{mmol} / \mathrm{l}$ arginine. Data are means $\pm \mathrm{SD}$, $* p<0.05, * * p<0.01$ compared with control; $n=4-6$

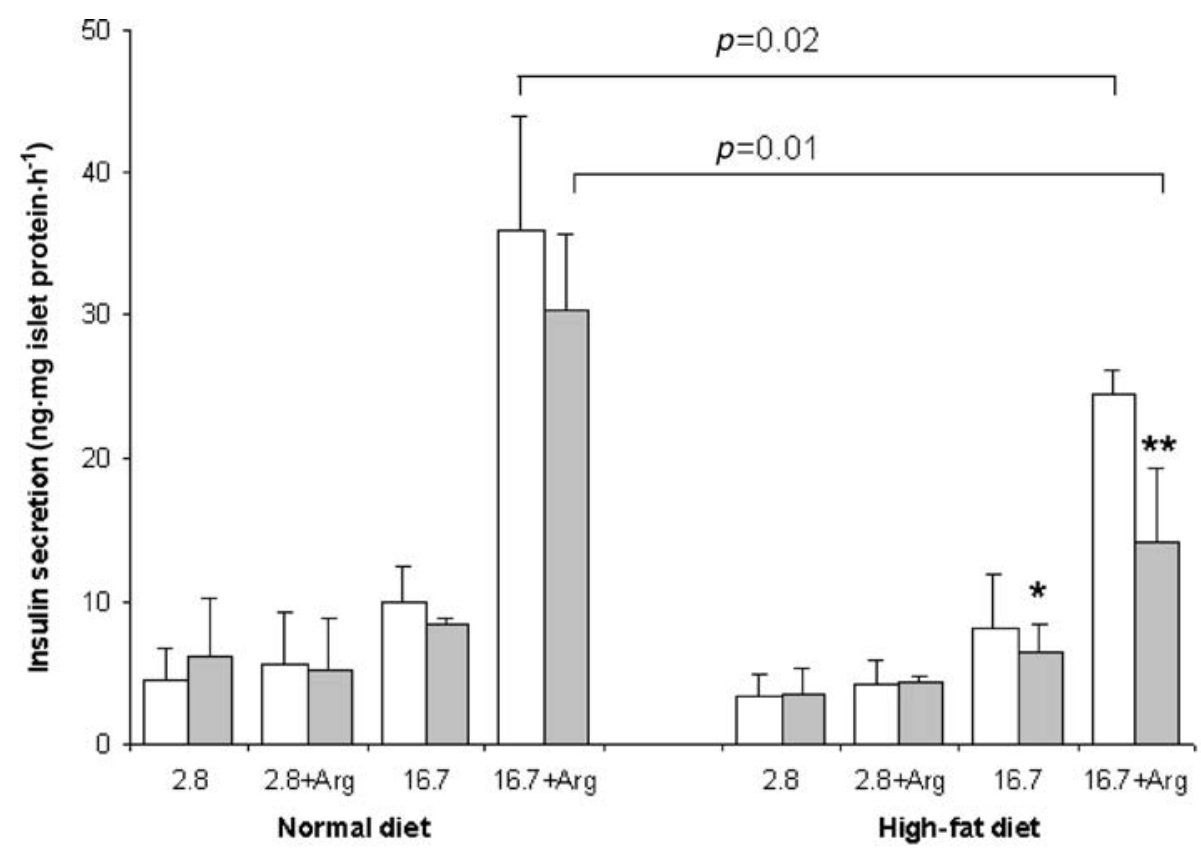



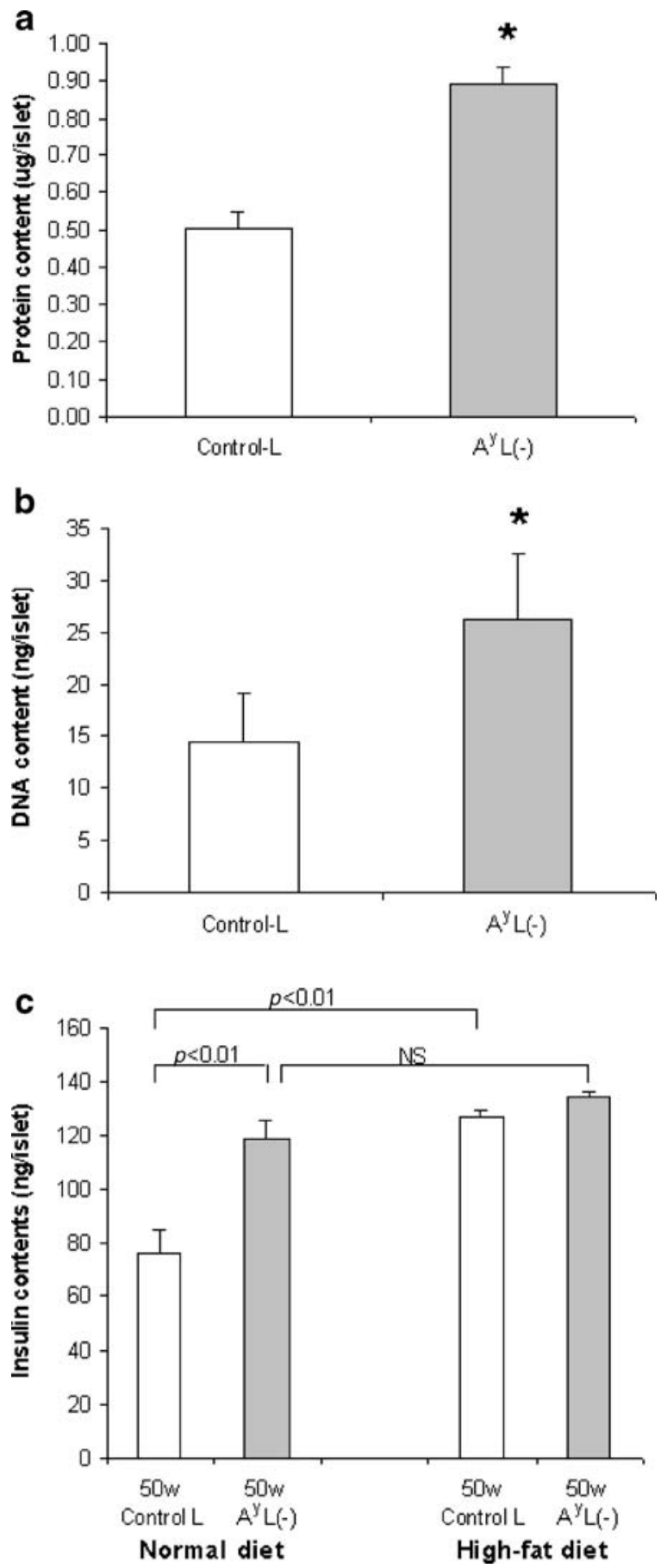

Fig. 6 Islet protein (a), DNA (b) and insulin (c) contents in 50week-old control and Agouti-negative female offspring fed with a normal (a, b and c) and a high-fat $\operatorname{diet}(\mathbf{c}) . A^{y} \mathrm{~L}(-)$, Agouti-negative offspring; L, control offspring. Data are means \pm SD. $* p<0.01$ compared with control; $n=6$

control islets as indicated by increased protein, DNA and insulin content. In addition, we found that $A^{y}$-negative female islets had markedly reduced transketolase and GAPDH activities. Transketolase is important for the pentose phosphate shunt that is needed for nucleic acid
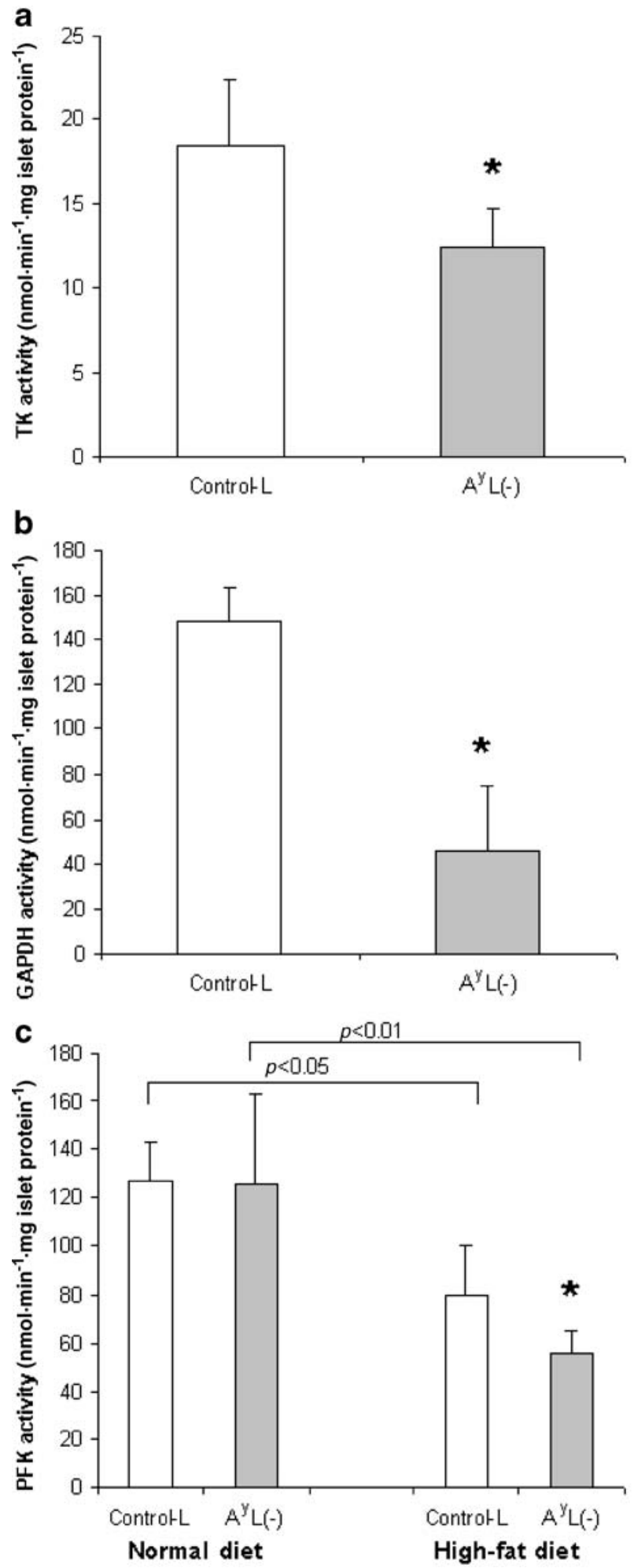

Fig. 7 Islet transketolase, GAPDH and PFK activity in 50-week-old control and Agouti-negative female offspring fed with a normal (a, b and c) and high-fat diet (c). $A^{y} \mathrm{~L}(-)$, Agouti-negative offspring; L, control offspring. ${ }^{*} p<0.01$ compared with control. Data are means \pm $\mathrm{SD} ; n=6$ 
precursors [22] and may reduce high glucose stress [21]. Low transketolase may render $A^{y}$-negative islets vulnerable to additional damage. Low GAPDH may limit glycolytic flux and this could contribute to the impairment of glucose stimulated insulin secretion. We obtained low islet yields from high-fat fed mice; as a result we could not perform all assays on these islets. However, we were able to determine that high-fat feeding did not increase insulin content in $A^{y}$-negative islets as it did in control islets. In addition, high-fat feeding caused a more severe decline in islet PFK activity in $A^{y}$-negative islets. Both the failure to increase insulin content and the greater loss of PFK activity may have contributed to the decline in islet function of high-fat fed $A^{y}$-negative islets.

The mechanisms by which maternal obesity impairs islet function in offspring are unknown. The fact that the change can be seen a full 50 weeks after delivery indicates that maternal obesity induces a change in developmental programming of the islet with permanent consequences for beta-cell function. Obesity is associated with abnormalities of lipid metabolism [30]. Maternal non-estirified fatty acids can cross the placenta, and placental lipoprotein lipase hydrolyses triglycerides to fatty acids that can cross the placenta [31, 32]. Thus, increased serum levels of maternal fatty acids and triglycerides may increase fatty acid transfer to the fetus. Triglyceride levels are elevated in newborn infants of obese, nondiabetic mothers, in comparison with control subjects [33]. Fatty acids are known to have detrimental effects on the adult beta cell $[29,34]$ and they may effect beta cell development as well. Oxidative stress occurs in the embryo during diabetic pregnancy [35], and also in the placenta of obese women [36]. It is possible that obese pregnancy leads to beta cell oxidative stress that disrupts normal programming. Whatever the mechanism of damage, it was evident that female offspring were significantly and reproducibly more sensitive than male offspring. Other type 2 diabetes models exhibit a sex bias; however, this is generally towards greater sensitivity of males [37, 38]. Maternal obesity must have a different mode of damage to beta cells.

Summary In summary, we have shown that maternal obesity causes glucose intolerance and a significant reduction in glucose-stimulated insulin secretion in $A^{y}$ negative female offspring. Islet protein, DNA and insulin content in female offspring were increased but transketolase, GAPDH and PFK activities were reduced. These changes in $A^{y}$-negative female offspring may contribute to the development of gestational diabetes and type 2 diabetes in later life. These results imply that the detrimental impact of maternal obesity on the beta cell may be another factor contributing to the epidemic of type 2 diabetes.

Acknowledgements This work was supported by grants to Y. Q. Liu from the National Institutes of Health (P20 RR/DE17702 from the COBRE Program of the National Center for Research Resources) and the American Diabetes Association (Junior Faculty Award) and by grant DK58100 (P.N.E.). The authors wish to acknowledge the expert technical help of Barry Billings.

\section{References}

1. Ehrenberg HM, Dierker L, Milluzzi C, Mercer BM (2002) Prevalence of maternal obesity in an urban center. Am J Obstet Gynecol 187:1189-1193

2. Mokdad AH, Serdula MK, Dietz WH et al (1999) The spread of the obesity epidemic in the United States, 1991-1998. JAMA 282:1519-1522

3. Galtier-Dereure F, Boegner C, Bringer J (2000) Obesity and pregnancy: complications and cost. Am J Clin Nutr 71:1242S$1248 \mathrm{~S}$

4. Gross T, Sokol RJ, King KC (1980) Obesity in pregnancy: risks and outcome. Obstet Gynecol 56:446-450

5. Cnattingius S, Bergstrom R, Lipworth L, Kramer MS (1998) Prepregnancy weight and the risk of adverse pregnancy outcomes. N Engl J Med 338:147-152

6. Levin BE, Govek E (1998) Gestational obesity accentuates obesity in obesity-prone progeny. Am J Physiol 275:R1374R1379

7. Aerts L, Holemans K, Van Assche FA (1990) Maternal diabetes during pregnancy: consequences for the offspring. Diabetes Metab Rev 6:147-167

8. Gauguier D, Bihoreau MT, Ktorza A et al (1990) Inheritance of diabetes mellitus as consequence of gestational hyperglycemia in rats. Diabetes 39:734-739

9. Van Assche FA, Aerts L, Holemans K (1991) The effects of maternal diabetes on the offspring. Baillieres Clin Obstet Gynaecol 5:485-492

10. Plagemann A, Harder T, Kohlhoff R et al (1997) Overweight and obesity in infants of mothers with long-term insulin-dependent diabetes or gestational diabetes. Int J Obes Relat Metab Disord 21:451-456

11. Pettitt DJ, Aleck KA, Baird HR et al (1988) Congenital susceptibility to NIDDM. Role of intrauterine environment. Diabetes 37:622-628

12. Thomas F, Balkau B, Vauzelle-Kervroedan F, Papoz L (1994) Maternal effect and familial aggregation in NIDDM. The CODIAB study. CODIAB-INSERM-ZENECA study group. Diabetes 43:63-67

13. DeFronzo RA, Bonadonna RC, Ferrannini E (1992) Pathogenesis of NIDDM. A balanced overview. Diabetes Care 15:318 368

14. Leahy JL (1990) Natural history of beta-cell dysfunction in NIDDM. Diabetes Care 13:992-1010

15. Klebig ML, Wilkinson JE, Geisler JG, Woychik RP (1995) Ectopic expression of the agouti gene in transgenic mice causes obesity, features of type II diabetes, and yellow fur. Proc Natl Acad Sci U S A 92:4728-4732

16. Gotoh M, Maki T, Satomi S et al (1987) Reproducible high yield of rat islets by stationary in vitro digestion following pancreatic ductal or portal venous collagenase injection. Transplantation 43:725-730

17. Liu YQ, Tornheim K, Leahy JL (1998) Fatty acid-induced beta cell hypersensitivity to glucose. Increased phosphofructokinase activity and lowered glucose-6-phosphate content. J Clin Invest 101:1870-1875

18. Labarca C, Paigen K (1980) A simple, rapid, and sensitive DNA assay procedure. Anal Biochem 102:344-352

19. Lambeir AM, Loiseau AM, Kuntz DA et al (1991) The cytosolic and glycosomal glyceraldehyde-3-phosphate dehydrogenase from Trypanosoma brucei. Kinetic properties and comparison with homologous enzymes. Eur J Biochem 198: 429-435

20. Wentzel P, Ejdesjo A, Eriksson UJ (2003) Maternal diabetes in vivo and high glucose in vitro diminish GAPDH activity in rat embryos. Diabetes 52:1222-1228

21. Hammes HP, Du X, Edelstein D et al (2003) Benfotiamine blocks three major pathways of hyperglycemic damage and prevents experimental diabetic retinopathy. Nat Med 9:294-299

22. Kochetov GA (1982) Transketolase from yeast, rat liver, and pig liver. Methods Enzymol 90 (Pt E):209-223 
23. Dabelea D, Pettitt DJ, Hanson RL et al (1999) Birth weight, type 2 diabetes, and insulin resistance in Pima Indian children and young adults. Diabetes Care 22:944-950

24. Dabelea D, Pettitt DJ (2001) Intrauterine diabetic environment confers risks for type 2 diabetes mellitus and obesity in the offspring, in addition to genetic susceptibility. J Pediatr Endocrinol Metab 14:1085-1091

25. Gauguier D, Nelson I, Bernard C et al (1994) Higher maternal than paternal inheritance of diabetes in GK rats. Diabetes 43: 220-224

26. Aerts L, Van Assche FA (1979) Is gestational diabetes an acquired condition? J Dev Physiol 1:219-225

27. Keil U, Kuulasmaa K (1989) WHO MONICA project: risk factors. Int J Epidemiol 18:S46-S55

28. Chen S, Ogawa A, Ohneda M et al (1994) More direct evidence for a malonyl-CoA-carnitine palmitoyltransferase I interaction as a key event in pancreatic beta-cell signaling. Diabetes 43:878-883

29. Shimabukuro M, Zhou YT, Levi M, Unger RH (1998) Fatty acid-induced beta cell apoptosis: a link between obesity and diabetes. Proc Natl Acad Sci U S A 95:2498-2502

30. Chan DC, Barrett HP, Watts GF (2004) Dyslipidemia in visceral obesity: mechanisms, implications, and therapy. Am J Cardiovase Drugs 4:227-246

31. Knopp RH, Warth MR, Charles D et al (1986) Lipoprotein metabolism in pregnancy, fat transport to the fetus, and the effects of diabetes. Biol Neonate 50:297-317
32. Bonet B, Brunzell JD, Gown AM, Knopp RH (1992) Metabolism of very-low-density lipoprotein triglyceride by human placental cells: the role of lipoprotein lipase. Metabolism 41:596-603

33. Kliegman R, Gross T, Morton S, Dunnington R (1984) Intrauterine growth and postnatal fasting metabolism in infants of obese mothers. J Pediatr 104:601-607

34. El Assaad W, Buteau J, Peyot ML et al (2003) Saturated fatty acids synergize with elevated glucose to cause pancreatic betacell death. Endocrinology 144:4154-4163

35. Eriksson UJ, Borg LA (1993) Diabetes and embryonic malformations. Role of substrate-induced free-oxygen radical production for dysmorphogenesis in cultured rat embryos. Diabetes 42:411-419

36. Walsh SW (1998) Maternal-placental interactions of oxidative stress and antioxidants in preeclampsia. Semin Reprod Endocrinol 16:93-104

37. Janson J, Soeller WC, Roche PC et al (1996) Spontaneous diabetes mellitus in transgenic mice expressing human islet amyloid polypeptide. Proc Natl Acad Sci U S A 93:7283-7288

38. Leiter EH, Kintner J, Flurkey K et al (1999) Physiologic and endocrinologic characterization of male sex-biased diabetes in C57BLKS/J mice congenic for the fat mutation at the carboxypeptidease E locus. Endocrine 10:57-66 